\title{
KEDUDUKAN FUNGSI LEGISLASI DPRD DALAM PEMBENTUKAN PERATURAN DAERAH PASCA AMANDEMEN UUD 1945
}

Marwan

Universitas Ichsan Gorontalo

Email: marwandjafar19@yahoo.com

Andi Risma

Universitas Muslim Indonesia

\begin{abstract}
One of the most fundamental functions of DPRD in the context of the implementation of regional autonomy is the function of forming regional regulations or legislative functions. The weakness of the DPRD in carrying out the function of forming local regulations began at the low initiative of the members of the Gorontalo Province DPRD making regional regulations (legislative initation); Likewise, there was also a weakness in the discussion of the proposed program for the formation of regional regulations on the proposal of the DPRD to become a regional regulation (law making process). The Regional Regulatory Forming Board (Bapemperda) as a DPRD instrument which is a DPRD instrument must be more focused on implementing legislation as the DPRD's main function
\end{abstract}

Keywords: Legislation Function, Regional Regulations

\begin{abstract}
Abstrak
Salah satu fungsi DPRD yang sangat fundamental dalam rangka penyelenggaraan otonomi daerah adalah fungsi membentuk peraturan daerah atau fungsi lagislasi. Kelemahan DPRD dalam menjalankan fungsi pembentukan peraturan daerah bermula pada rendahnya Prakarsa anggota DPRD Provinsi Gorontalo pembuatan peraturan daerah (legislative initation); demikian juga terjadi kelemahan pada Pembahasan usulan program pembentukan peraturan daerah atas usulan DPRD menjadi peraturan daerah (law making process). Badan Pembentukan Peraturan Daerah (Bapemperda) sebagai alat kelengkapan DPRD yang merupakan alat kelengkapan DPRD harus lebih fokus menjalankan legislasi sebagai fungsi utama DPRD
\end{abstract}

Kata Kunci : Fungsi Legislasi, Peraturan Daerah 


\section{PENDAHULUAN}

Pemberian otonomi yang seluas-seluasnya kepada Daerah dilaksanakan berdasarkan prinsip negara kesatuan. Dalam negara kesatuan kedaulatan hanya ada pada pemerintah pusat dan tidak ada kedaulatan pada daerah. Oleh karena itu, seluas apa pun otonomi yang diberikan kepada daerah, tanggung jawab akhir penyelenggaraan Pemerintahan Daerah akan tetap ada ditangan Pemerintah Pusat. Untuk itu Pemerintahan Daerah pada negara kesatuan merupakan satu kesatuan dengan Pemerintahan Nasional. Sehingga kebijakan yang dibuat dan dilaksanakan oleh daerah merupakan bagian integral dari kebijakan nasional. Kewenangan terletak pada bagaimana memanfaatkan kearifan, potensi, inovasi, daya saing, dan kreativitas untuk mencapai tujuan nasional tersebut di tingkat lokal yang pada gilirannya akan mendukung pencapaian tujuan nasional secara keseluruhan.

Daerah sebagai satu kesatuan masyarakat hukum yang mempunyai otonomi berwenang mengatur dan mengurus daerahnya sesuai aspirasi dan kepentingan masyarakatnya sepanjang tidak bertentangan dengan tatanan hukum nasional dan kepentingan umum. Dalam rangka memberikan ruang yang lebih luas kepada daerah untuk mengatur dan mengurus kehidupan warganya maka Pemerintah Pusat dalam membentuk kebijakan harus memperhatikan kearifan lokal dan sebaliknya daerah ketika membentuk kebijakan daerah baik dalam bentuk Peratuan Daerah maupun kebijakan lainnya hendaknya juga memperhatikan kepentingan nasional. Dengan demikian akan tercipta keseimbangan antara kepentingan nasional yang sinergis dan tetap memperhatikan kondisi, kekhasan, dan kearifan lokal dalam penyelenggaraan pemerintahan secara keseluruhan.

Pada hakikatnya otonomi daerah diberikan sebagai satu kesatuan masyarakat hukum yang diberi kewenangan untuk mengatur dan mengurus sendiri urusan Pemerintahan yang diberikan oleh Pemerintah Pusat kepada Daerah dan dalam pelaksanaannya dilakukan oleh kepala daerah dan DPRD. Urusan Pemerintahan yang diserahkan ke Daerah berasal dari kekuasaan pemerintahan yang ada ditangan Presiden. Konsekuensi dari negara kesatuan adalah tanggung jawab akhir pemerintahan ada ditangan Presiden. Agar pelaksanaan Urusan Pemerintahan yang diserahkan ke daerah berjalan sesuai dengan kebijakan nasional maka Presiden berkewajiban untuk melakukan pembinaan dan pengawasan terhadap penyelenggaraan Pemerintahan Daerah.

DPRD dan kepala daerah berkedudukan sebagai unsur penyelenggara pemerintahan daerah yang diberi mandat oleh rakyat untuk melaksanakan urusan Pemerintahan yang diserahkan kepada Daerah. Dengan demikian maka DPRD dan kepala daerah berkedudukan sebagai mitra sejajar yang mempunyai fungsi 
yang berbeda. DPRD mempunyai fungsi pembentukan Peratuan Daerah, anggaran dan pengawasan, sedangkan kepala daerah memiliki tugas melaksanakan Peratuan Daerah dan kebijakan Daerah.

Sebagai konsekuensi posisi DPRD sebagai unsur penyelenggara Pemerintahan Daerah maka susunan, kedudukan, peran, hak, kewajiban, tugas, wewenang, dan fungsi DPRD diatur dalam konstitusi Negara UUD Negara 1945 dan peraturan perundang-undangan lainnya.

Dalam melaksanakan Urusan Pemerintahan yang menjadi kewenangan Daerah, kepala daerah dan DPRD selaku penyelenggara Pemerintahan Daerah membuat Peratuan Daerah sebagai dasar hukum bagi daerah dalam menyelenggarakan otonomi daerah sesuai dengan kondisi dan aspirasi masyarakat serta kekhasan dari daerah tersebut. Peratuan Daerah yang dibuat oleh DPRD bersama kepala daerah hanya berlaku dalam batas-batas yurisdiksi daerah yang bersangkutan. Walaupun demikian Peratuan Daerah yang ditetapkan oleh daerah tidak boleh bertentangan dengan ketentuan peraturan perundang-undangan yang lebih tinggi tingkatannya sesuai dengan hierarki peraturan perundang-undangan. Disamping itu Peratuan Daerah sebagai bagian dari sistem peraturan perundangundangan tidak boleh bertentangan dengan kepentingan umum sebagaimana diatur dalam kaidah penyusunan Peratuan Daerah.

Hal tersebut diatur dalam Pasal 18 ayat(2) Undang-Undang Dasar Negara Republik Indonesia Tahun 1945 yang menjelaskan bahwa Pemerintah Daerah berwenang untuk mengatur dan mengurus sendiri urusan pemerintahan menurut asas otonomi dan tugas pembantuan dalam sistem Negara Kesatuan Republik Indonesia. Penyelenggaraan pemerintahan dalam suatu Negara tidak hanya terdapat di pusat pemerintahan saja akan tetapi Pemerintah pusat memberikan wewenangnya kepada Pemerintah daerah untuk menyelenggarakan pemerintahannya sendiri.

Maka dari itu otonomi daerah pada hakekatnya adalah sebagai perwujudan desentralisasi kepada daerah untuk mengatur dan mengurus sendiri urusan pemerintahan yang diberikan oleh pemerintah pusat kepada daerah, ${ }^{1}$ alasannya bahwa Pemerintah Daerah yang lebih mengetahui keadaan dan kondisi di daerahnya. Dengan adanya kewenangan untuk mengatur dan mengurus rumah tangganya sendiri berdasarkan Undang-Undang Nomor 23 Tahun 2014 tentang Pemerintahan Daerah, maka mengharuskan pemerintahan di daerah membentuk regulasi-regulasi dalam upaya melaksanakan roda pemerintahan di daerah yaitu

1 Tjahjo Kumolo dan Tim, Nawa Cita untuk Kesejahteraan Rakyat Indonesia Integrasi Perencanaan Pembangunan Nasional dan Daerah, (Jakarta: PT. Kompas Media Nusantara, 2017), hlm 17. 
dengan melahirkan peraturan daerah (Peratuan Daerah) yang sesuai dengan kebutuhan dan kondisi daerah.

Kewenangan Pemerintahan Daerah dalam membentuk peraturan daerah mempunyai legitimasi secara yuridis formal didasari dalam Pasal 18 ayat (6) UUD NRI Tahun 1945 yang menyatakan bahwa "Pemerintahan Daerah berhak menetapkan peraturan daerah dan peraturan-peraturan lain untuk melaksanakan otonomi dan tugas pembantuan." Pasal 242 ayat (1) Undang-Undang Nomor 23 Tahun 2014 tentang Pemerintahan Daerah yang menyatakan bahwa "Rancangan peraturan daerah disetujui bersama oleh DPRD dan Kepala Daerah disampaikan oleh Pimpinan DPRD kepada Kepala Daerah untuk ditetapkan menjadi Peraturan Daerah." Serta Pasal 96 (1) mengatur dengan tegas bahwa DPRD provinsi mempunyai fungsi: a. pembentukan Peratuan Daerah provinsi; b. anggaran; dan c. pengawasan. ${ }^{2}$

Legislasi merupakan salah satu fungsi DPRD pada tingkat daerah. Pada hakekatnya, fungsi legislasi adalah fungsi membentuk peraturan daerah. Secara ideal pelaksanaan fungsi legislasi diharapkan dapat menciptakan peraturan daerah yang aspiratif dan responsif sebagai kewajiban sekaligus kewenangan yang dimiliki oleh pembuat undang-undang karena pemberian kewenangan dalam menetapkan Peraturan daerah sebagai upaya untuk memberikan keleluasaan kepada daerah sesuai dengan kondisi lokalistiknya ${ }^{3}$.

Salah satu fungsi DPRD yang sangat fundamental dalam rangka penyelenggaraan otonomi daerah adalah fungsi membentuk peraturan daerah. Untuk melaksanakan fungsi tersebut DPRD diberi bermacam-macam hak yang salah satunya ialah "hak mengajukan rancangan peraturan daerah dan hak mengadakan perubahan atas rancangan peraturan daerah" sehingga dengan demikian DPRD memiliki kedudukan yang lebih strategis dalam pembentukan peraturan.

\footnotetext{
2 Rancangan Perda berasal dari DPRD dan Pemerintah daerah serta fungsi-fungsi DPRD dan khususnya khususnya fungsi pembentukan peraturan daerah Provinsi.Hal ini di atur dalam Undang-Undang Nomor 23Tahun 2014 tentang Pemerintahan Daerah (Lembaran Negara Republik Indonesia Tahun 2014 Nomor 244, Tambahan Lembaran Negara Republik Indonesia Nomor 5587) sebagaimana telah diubah beberapa kali terakhir dengan Undang-Undang Nomor 9 Tahun 2015 tentang Perubahan Kedua Atas UndangUndang Nomor 23 Tahun 2014 tentang Pemerintahan Daerah (Lembaran Negara Republik Indonesia Tahun 2015 Nomor 58, Tambahan Lembaran Negara Republik Indonesia Nomor 5679);

3 Bandiyah dkk, Analisis Kinerja Dewan Perwakilan Rakyat Daerah Tahun 2009-2014 (Studi Kasus: Kabupaten Toli-Toli, Sulawesi Tengah), Jurnal FISIP Universitas Udayana, (Bali: Universitas Udayana, 2014), hlm 1
} 
Berdasarkan hal tersebut di atas, maka fungsi membentuk peraturan daerah pada DPRD Provinsi Gorontalo dijadikan sebagai bahan kajian dalam penelitian ini terutama dalam menjalankan penggunaan hak mengajukan rancangan peraturan daerah usul DPRD. Seharusnya fungsi ini merupakan fungsi paling dominan dan berpengaruh karena melalui fungsi ini maka DPRD dapat mempengaruhi seluruh aspek kebijakan yang ada di daerah Provinsi, Kabupaten dan/atau Kota. Hal ini juga merupakan salah satu amanat amandemen UUD Negara RI bahwa kewenangan pembentukan undang-undang maupun peraturan daerah terjadi pergeseran dari eksekutif kepada Dewan Perwakilan Rakyat (Daerah) namun sampai saat ini khususnya fungsi pembentukan peraturan daerah di Provinsi Gorontalo dinilai kurang produktif karena dalam Propem Peratuan Daerah dalam Periode 2014-2019 usulan eksekutif masih lebih besar di banding usulan Dewan Perwakilan Rakyat Daerah.

\section{PEMBAHASAN}

Menurut sistem hukum Indonesia, secara normatif Peratuan Daerah termasuk salah satu jenis dan hierarki peraturan perundang-undangan sebagaimana diatur dalam Pasal 7 ayat (1) Undang-Undang Nomor 12 tahun 2011 yang menyebutkan bahwa :

(1) Jenis dan hierarki Peraturan Perundang-undangan terdiri atas:

a. Undang-Undang Dasar Negara Republik Indonesia Tahun 1945;

b. Ketetapan Majelis Permusyawaratan Rakyat;

c. Undang-Undang/Peraturan Pemerintah Pengganti Undang-Undang;

d. Peraturan Pemerintah;

e. Peraturan Presiden;

f. Peraturan Daerah Provinsi; dan

g. Peraturan Daerah Kabupaten/Kota.

Fungsi Legislasi DPRD Provinsi, Kabupaten/Kota merupakan salah satu kewenangan atribusi yang melekat pada DPRD dalam pembentukan peraturan daerah yang di mulai pada tahap perencanaan, penyusunan,pembahasan dan pengundangan. Fungsi legislasi mengalami pergeseran yang memberikan kewenangan kepada dewan Perwakilan Rakyat maupun Dewan Perwakilan Rakyat Daerah ( DPRD) untuk membentuk peraturan daerah. Sehingga idealnya pembentukan peraturan daerah seharusnya lebih didominasi oleh DPRD di banding pihak eksekutif (pemerintah daerah).

DPRD dalam menjalankan fungsi pembentukan peraturan daerah di Provinsi Gorontalo dilaksanakan oleh 45 (empat puluh lima) orang anggota DPRD, tentunya dari jumlah tersebut diharapkan dapat memberikan kontribusi 
yang lebih produktif dalam pembentukan peraturan daerah yang lebih responsif demi memajukan kesejahteraan masyarakat. Karena dalam UU Nomor 23 Tahun 2014 selain DPRD memiliki fungsi membentuk peraturan daerah provinsi, maka setiap anggota DPRD juga memiliki hak untuk mengajukan rancangan peraturan daerah atau sering disebut hak usul inisiatif anggota DPRD.

Fungsi legislasi dalam pembentukan peraturan daerah adalah kewenangan dalam pembentukan peraturan daerah, yaitu menginisiasi lahirnya rancangan peraturan daerah dan juga membahas serta menyetujui atau menolak rancangan peraturan daerah yang diusulkan oleh pihak eksekutif ${ }^{4}$.

Berdasarkan hasil penelitian, bahwa Pelaksanaan fungsi legislasi DPRD Provinsi Gorontalo Periode 2014-2019 dalam pembentukan peraturan daerah pasca amandemen UUD Negara Republik Indonesia 1945 belum berjalan secara maksimal, hal dapat dilihat pada tabel berikut :

Tabel 1

Daftar Program Pembentukan Peraturan Daerah (Propemperda)

Provinsi Gorontalo Tahun 2014-2018

\begin{tabular}{|c|c|c|c|c|}
\hline No & Tahun & $\begin{array}{c}\text { Usulan } \\
\text { legislatif }\end{array}$ & $\begin{array}{c}\text { Usulan } \\
\text { eksekutif }\end{array}$ & Jumlah \\
\hline 1 & 2014 & 7 & 17 & 24 \\
\hline 2 & 2015 & 11 & 16 & 27 \\
\hline 3 & 2016 & 12 & 15 & 27 \\
\hline 4 & 2017 & 10 & 11 & 21 \\
\hline 5 & 2018 & 8 & 14 & 22 \\
\hline & Jumlah & 48 & 73 & 121 \\
\hline
\end{tabular}

Sumber Data : Biro Hukum Provinsi Gorontalo, 2019

Berdasarkan tabel diatas nampak bahwa anggota DPRD Provinsi Gorontalo periode 2014-2019 dalam mengajukan program pembentukan peraturan daerah (Propemperda) sebagaimana amanat amandemen Konstitusi UUD Negara Republik Indonesia 1945 dan UU No.23 Tahun 2014 tentang Pemerintahan Daerah belum berjalan dengan maksimal. Dari data tersebut dapat dilihat bahwa program pembentukan peraturan daerah (Propemperda) dalam jangka waktu 5 (lima ) tahun terakhir pihak eksekutif masih lebih mendominasi dibanding dengan DPRD. Dominasi eksekutif dalam pengajuan rancangan peraturan daerah tampak bahwa pada tahun 2014 DPRD hanya 29,16\% keaktipannya dalam mengajukan

\footnotetext{
${ }^{4}$ Dadang Solihin, Peran Tenaga Ahli DPRD Dalam Perumusan Kebijakan Publik Guna Mendukung Fungsi Pengawasan,
} Penganggaran dan Legislasi, (Jakarta: Modul Dialog Rektor dengan Tenaga Ahli DPRD Kabupaten Merauke, 2016), hlm 8 
raperda, pada tahun 2015 DPRD hanya 40,78\% mengajukan raperda, 2016 DPRD hanya 44,44\% mengajukan raperda, kemudian pada tahun 2017 hanya 47,61\% DPRD mengajukan Raperda dan pada tahun 2018 DPRD hanya 36,36\% dalam mengajukan raperda. Hal ini sesuai dengan pandangan Ferry Rezeki ( Kasubag Pembinaan dan Kajian Produk Hukum Daerah Biro Hukum dan Organisasi Setda Provinsi Gorontalo) yang menegaskan bahwa pengusulan rancangan peraturan daerah yang ditetapkan program pembentukan peraturan daerah (propemperda) di Provinsi Gorontalo selama beberapa tahun terakhir lebih banyak yang berasal dari eksekutif melalui organisasi perangkat daerah di bandingkan dengan usulan yang berasal dari pihak DPRD maupun anggota DPRD (wawancara, 10 Mei 2019).

Hal yang sama di kemukakan oleh H.Marwan D Ngiu,SH (Anggota DPRD Provinsi Gorontalo) mengatakan bahwa pelaksanaan fungsi DPRD dalam pembentukan peraturan daerah khusunya pengusulan rancangan peraturan daerah, secara kuantitatif masih tergolong belum maksimal jika di bandingkan dengan usulan yang bersumber dari eksekutif (wawancara, 17 Mei 2019).

Berdasarkan uraian data di atas, maka anggota DPRD Provinsi Gorontalo khususnya periode 2014-2019 belum menjalankan fungsinya sebagaimana diatur dalam Pasal 96 UU Nomor 23 Tahun 2014 tentang Pemerintahan Daerah bahwa DPRD provinsi mempunyai fungsi pembentukan Perda provinsi; demikian halnya DPRD provinsi Gorontalo belum menjalankan salah satu tugasnya sebagaimana di atur dalam Pasal 101 ayat (1) huruf a yaitu membentuk peraturan daerah bersama gubernur demikian juga DPRD provinsi Gorontalo belum menjalankan salah satu haknya dengan sebagaimana di atur dalam Pasal 107 huruf a UU No.23 tahun 2014 tentang Pemerintahan Daerah yaitu anggota DPRD berhak mengajukan rancangan Peratuan Daerah Provinsi sehingga berdampak juga pada tidak maksimalnya pelaksanaan fungsi DPRD dalam pembentukan peraturan daerah.

Selanjutnya penulis menguraikan realisasi program pembentukan peraturan daerah (PropemPeratuan Daerah) menjadi peraturan daerah di Provinsi Gorontalo tahun 2014-2018, sebagaimana diuraikan pada table berikut : 
Tabel 2

Capain Pembentukan Peraturan Daerah Provinsi Gorontalo

Tahun 2014-2018

\begin{tabular}{|c|c|c|c|c|}
\hline No & Tahun & $\begin{array}{c}\text { Usulan } \\
\text { legislatif }\end{array}$ & $\begin{array}{c}\text { Usulan } \\
\text { Eksekutif }\end{array}$ & Jumlah \\
\hline 1 & 2014 & 3 & 12 & 15 \\
\hline 2 & 2015 & 6 & 10 & 16 \\
\hline 3 & 2016 & 6 & 7 & 13 \\
\hline 4 & 2017 & 4 & 6 & 10 \\
\hline 5 & 2018 & 1 & 6 & 7 \\
\hline & Jumlah & 20 & 41 & 61 \\
\hline
\end{tabular}

Sumber Data : Biro Hukum Provinsi Gorontalo, 2019

Berdasarkan data pada tabel 2 (dua) diatas dapat diketahui bahwa capaian pelaksanaan fungsi DPRD Provinsi Gorontalo dalam pembentukan peraturan daerah belum berjalan dengan maksimal. Hal ini tampak bahwa pada tahun 2014 dari 7 (tujuh) usulan PropemPeratuan Daerah oleh DPRD hanya 3 yang menjadi Peraturan daerah, kemudian pada tahun 2015 dari 11 usulan PropemPeratuan Daerah usul DPRD hanya 6 yang menjadi Peraturan daerah, selanjutnya pada tahun 2016 dari 12 usulan PropemPeratuan Daerah oleh DPRD hanya 6 yang menjadi Peraturan daerah, kemudian pada tahun 2017 dari 10 usulan PropemPeratuan Daerah oleh DPRD hanya 4 yang menjadi Peraturan daerah dan pada tahun 2018 adalah capaian yang paling rendah pelaksanaan fungsi DPRD dalam pembentukan peraturan daerah yaitu dari 8 usulan PropemPeratuan Daerah oleh DPRD hanya 1 yang menjadi Peraturan daerah.

Kelemahan DPRD dalam menjalankan fungsi pembentukan peraturan daerah bermula pada rendahnya Prakarsa anggota DPRD Provinsi Gorontalo pembuatan peraturan daerah (legislative initation); demikian juga terjadi kelemahan pada Pembahasan usulan program pembentukan peraturan daerah atas usulan DPRD menjadi peraturan daerah (law making process);

Lain halnya dengan anggota DPRD dalam proses memberikan Persetujuan atas pengesahan rancangan peraturan daerah (law enactement approval) atas usulan eksekutif nampak lebih aktif. Hal ini dapat dilihat bahwa pada tahun 2014 usulan rancangan peraturan daerah oleh eksekutif sebanyak 17 yang mendapat persetujuan DPRD sebanyak 12 menjadi peraturan daerah, kemudian pada tahun 2015 usulan sebanyak 16 yang disetujui menjadi peraturan daerah sebanyak 10 dan pada tahun 2016 usulan eksekutif sebanyak 15 yang disetujui sebanyak 7 menjadi peraturan daerah kemudian pada tahun 2017 sebanyak 11 yang disetujui 
menjadi peraturan daerah sebanyak 6 menjadi peraturan daerah serta pada tahun 2018 sebanyak 14 usulan rancangan peraturan daerah dan yang disetujui sebanyak 6 menjadi peraturan daerah.

Terkait dengan belum maksimalnya pelaksanaan fungsi legislasi DPRD dalam pembentukan peraturan daerah maka seharusnya Badan Pembentukan Peraturan Daerah (Bapemperda) sebagai alat kelengkapan DPRD yang khusus menangani bidang Legislasi, dituntut untuk mengoptimalkan fungsi dan tugas dari Badan Pembentukan Peraturan Daerah (Bapemperda) itu sendiri dalam rangka memberikan pemecahan permasalahan yang berkaitan dengan legislasi daerah khususnya yang berkaitan dengan pembentukan Peratuan Daerah sebagai salah fungsi DPRD yang di amantkan dalam UU No.23 Tahun 2014 tentang Pemerintahan Daerah.

Maka dari itu seharusnya Badan Pembentukan Peraturan Daerah (Bapemperda) sebagai alat kelengkapan DPRD yang menangani bidang legislasi melakukan penguatan fungsi legislasi DPRD melalui :

a. Keterlibatan Balegda dalam peningkatan kualitas dan produktivitas legislasi oleh DPRD

b. Kecukupan finasial dan sumber daya manusia.

c. Penyusunan anggota-anggota Badan Pembentukan Peraturan Daerah (BapemPeratuan Daerah) yang tepat yang bukan anggota komisi lainnya dan dengan demikian mempunyai cukup waktu untuk melakukan tugas-tugas pembentukan peraturan daerah.

d. Pembuatan Peratuan Daerah hendaknya disertai dengan analisis RIA ${\text { (Regulatory Impact Assessement })^{5}}$

sehingga dengan demikian maka anggota DPRD harus memahami bahwa Fungsi legislasi dalam pembentukan Peratuan Daerah merupakan fungsi utama DPRD dapat berjalan dengan baik. Marbun mengemukakan, bahwa "fungsi pembuatan Peratuan Daerah merupakan fungsi utama dan asli dari Dewan Perwakilan Rakyat Daerah sebagai badan legislatif. Lewat fungsi ini, DPRD dapat menunjukkan warna dan karakter serta kualitasnya, baik secara materil maupun secara fungsional ${ }^{6}$. Fungsi legislasi ini melekat kepada DPRD sebagaimana DPRD merupakan lembaga perwakilan rakyat.

\footnotetext{
${ }^{5}$ Forum Komunikasi Partai Politik dan Politisi untuk Reformasi, 2005, Konsolidasi Demokrasi (Kompilasi Hasil Workshop, Pertemuan kerja Rutin dan Pertemuan Nasional Forum Politisi, Forum Komunikasi Partai Politik dan Politisi untuk Reformasi, Jakarta, hal.74

${ }^{6}$ B.N. Marbun. 1983. DPRD Pertumbuhan, Masalah dan Masa Depannya. Jakarta: Ghalia Indonesia. Hlm.162
} 


\section{KESIMPULAN}

Kedudukan Fungsi legislasi DPRD pasca amandemen UUD 1945 mengalami pergeseran, hal mana bahwa pembentukan peraturan daerah provinsi DPRD seharusnya lebih produktif di banding dengan eksekutif, namun demikian fungsi tersebut belum maksimal dijalankan oleh DPRD, sehingga tampak dengan masih rendahnya prakarsa dan pembahasan rancangan peraturan daerah usul DPRD dalam kurung waktu 5 (lima) tahun terakhir. Untuk memaksimalkan pelaksanaan fungsi legislasi DPRD dalam pembentukan peraturan daerah, maka Badan Pembentukan Peraturan Daerah (Bapemprda) sebagai alat kelengkapan DPRD yang merupakan alat kelengkapan DPRD harus lebih fokus menjalankan legislasi sebagai fungsi utama DPRD. Selain itu DPRD Provinsi Gorontalo membangun kerjasama dengan Perguruan Tinggi dalam peningkatan kapasitas anggota DPRD dalam pembentukan peraturan daerah 


\section{DAFTAR PUSTAKA}

Achmad Ruslan, 2013, Teori dan Panduan Pembentukan Peraturan Perundangundangan Di Indonesia,Makakarya Rangkang, Yogyakarta.

Bandiyah dkk, Analisis Kinerja Dewan Perwakilan Rakyat Daerah Tahun 20092014 (Studi Kasus: Kabupaten Toli-Toli, Sulawesi Tengah), Jurnal FISIP Universitas Udayana, (Bali: Universitas Udayana, 2014),

Beni Ahmad Soebani, 2009, Metode Penelitian Hukum, Cet. Ke-1, (Bandung: Pustaka Setia )

B.N. Marbun. 1983. DPRD Pertumbuhan, Masalah dan Masa Depannya. Jakarta: Ghalia Indonesia.

Dadang Solihin, 2016, Peran Tenaga Ahli DPRD Dalam Perumusan Kebijakan Publik Guna Mendukung Fungsi Pengawasan, Penganggaran dan Legislasi, (Jakarta: Modul Dialog Rektor dengan Tenaga Ahli DPRD Kabupaten Merauke, )

Desmond King and Gerry Stoker, (Eds.), Rethingking Local Democracy,(London: Macmillan Press Ltd,1996),

Forum Komunikasi Partai Politik dan Politisi untuk Reformasi, 2005, Konsolidasi Demokrasi (Kompilasi Hasil Workshop, Pertemuan kerja Rutin dan Pertemuan Nasional Forum Politisi, Forum Komunikasi Partai Politik dan Politisi untuk Reformasi, Jakarta.

Kant dalam LG Saraswati, dkk, 2006, Hak Asasi Manusia, filsafat-UI Press, Jakarta,

Muhammad Idrus, 2007,Metode Penulisan Ilmu-Ilmu Social, (Yogyakarta: UII Press,)

Mukti Fajar dkk,2010, Dualisme Penelitian Hukum Normatif dan Empiris, (Yogyakarta: Pustaka Pelajar,);

Peter Mahmud Marzuki,2009, Penelitian Hukum,(Jakarta : Kencana Prenada Media Group).

Samsul Wahidin, 2013, Hukum Pemerintahan Daerah Pendulum Otonomi Daerah Dari Masa Ke Masa, (Yogyakarta: Pustaka Pelajar,) 